\title{
Effect of Mycorrhizal Application on Plant Growth and Nutrient Uptake of Piper mullesua Plantlets under Sterilized, Unsterilized and Field Soil Condition
}

\author{
Arundhati Bordoloi ${ }^{1 *}$ and A. K. Shukla ${ }^{2}$ \\ ${ }^{1}$ Krishi Vigyan Kendra, Sivasagar, Assam Agricultural University, India \\ ${ }^{2}$ Indira Gandhi National Tribal University, Amarkantak, MP, India \\ *Corresponding author
}

\begin{abstract}
A B S T R A C T
\section{Keywords}

Mycorrhizal fungi,

Sterilized soil,

Piper mullesua,

Plant biomass and

phosphatase

\section{Article Info}

Accepted:

23 April 2020

Available Online:

10 May 2020

Mycorrhizal fungi occur in most of the soils and colonize roots of many plant species. A greenhouse experiment was carried out to study the efficiency of Arbuscular Mycorrhizal fungi indigenous to Arunachal Pradesh in uptaking plant nutrients for the Piper mullesua plantlets at different soil condition i.e., sterilized soil, unsterilized soil and field condition. As the sterilized soil condition is difficult to understand the performance of AM fungi, field experiments are necessary to understand the effect of mycorrhizal fungi on yield of crops in field condition. The experiment was done to determine the effectiveness of mycorrhizal fungal inoculated with $P$. mullesua plantlets assessing its effect on plant growth and plant nutrition when compared with non-mycorrhizal $P$. mullesua plantlets in sterilized, unsterilized and field condition. For this ten different mycorrhizal fungal species isolated from various land use systems such as forest area, jhum fields, home gardens as well as natural habitat of piper plants were inoculated with the plantlets of $P$. mullesua in three different set of experiment. In present study G. claroidium $(2.238 \mathrm{gm} \pm 0.209)$, G. aggregatum $(2.122 \mathrm{gm} \pm 0.057)$ and $G$. versiforme $(2.109 \mathrm{gm} \pm 0.051)$ were found more capable in producing better growth by infecting Piper mullesua plantlets under field soil as compared to unsterilized and sterilized soil condition. Plant phosphatase content was significantly $(p>0.001)$ higher in the seedlings grown in unsterilized soil, followed by in field condition and least in the sterilized soil. These inocula were efficient in establishing beneficial relationship with other native microorganisms of soil. As chemical fertilizers possess threat to the environment by polluting soil and environment, these efficient mycorrhizal species can work as potential biofertilizer for agriculturally important crops.
\end{abstract}

\section{Introduction}

Piper mullesua D. Don. (syn $P$. brachystachyum Wall ex Hook. f), an important medicinal plant belonging to the family Piperaceae. It is commonly known as Pipli, Pahari peepal, is indigenous to Arunachal Pradesh (India) and widely distributed in the Eastern Himalayan region at an altitude of about $600 \mathrm{~m}$ to $1500 \mathrm{~m}$. Male and female flowers are found in separate spikes of the plant. Male spikes are 3-6 cm long, erect, slender and cylindrical. Female spikes are globose, oblong erect.

Roots and fruiting spikes are used in treating diarrhea, indigestion, jaundice, urticacia, abdominal disorder, horseness of voice, asthma, cough, piles, malaria fever, vomiting wheezing, chest conjestion, throat infection, worms and sinusitis. Piper mullesua is also considered as a rejuvenating plant. Myristicin, 
a 1,3-benzodioxole has been extracted from the hexane fraction of alcohol extract of fruit bearing inflorescence of Piper mullesua which has insecticidal properties (Srivastva et al., 2001).

Mycorrhizal fungi occur in most of the soils and colonize roots of many plant species. Mycorrhiza is the structures resulting from the symbiosis between these fungi and plant roots, and are directly involved in plant mineral nutrition. The symbiotic root-fungal association increases the uptake of less mobile nutrients (Ortas et al., 2001), essentially phosphorus (P) but also of micronutrients like zinc $(\mathrm{Zn})$ and copper $(\mathrm{Cu})$, the symbiosis has also been reported as influencing water uptake. AMF can also benefit plants by stimulating the production of growth regulating substances, increasing photosynthesis, improving osmotic adjustment under drought and salinity stresses and increasing resistance to pests and soil borne diseases (Al-Karaki, 2006).

The importance of mycorrhizae in plant growth and its role in ecosystem development has been overwhelmingly demonstrated in recent years. Establishment of ecologically adapted mycorrhizal fungi on plantlets before planting improve survival and growth rate of plants (Jha et al., 1988). These points can all be taken as strong evidence for a mutualistic symbiosis. Differences in the effectiveness of mycorrhizal species were also recorded by various workers (Mosse, 1972; Bevege and Bowen, 1975; Caravaca et al., 2006).

Some species such as the fine endophyte Glomus tenue, rarely produce growth responses, even in infertile soil (Powell, 1979), yet this is often the most abundant mycorrhizal fungus in natural soils. Almost all work on mycorrhizal effects was carried out in sterilized soil. As the sterilized soil condition is difficult to understand the performance of AM fungi, field experiments are necessary to understand the effect of mycorrhizal fungi on yield of crops in field condition. Pot experiments often examined the response of single plants, and in arable crops the individuals were typically wellspaced. In grasslands and most nonagricultural vegetation, however, the root systems of adjacent individuals overlap to a great extent. Mycorrhizal mycelium is known to be capable of linking plants physically, and transfer of $\mathrm{P}$ from one plant to another by mycorrhizal hyphae has been demonstrated (Whittingham and Read, 1982).

In recent years there has been considerable interest on plant growth promoting rhizobacteria (PGPR), which improve plant growth by providing growth promoting substances and suppressing root pathogens (Goswami et al., 2016; Olanrewaju et al., 2017). Synergistic interaction between AMF and PGPR benefitting the growth of plants compared to single inoculation with either of them has been reported by earlier workers (Cely et al., 2016, Divyananda et al., 2006). AMF and PGPR in soil and plant tissues mutually cooperate with each other in benefitting plant growth through increased nutrition, hyphal permeability in plant roots, bacterial survival and protection against biotic and abiotic stresses. Communication through signaling molecules, such as flavonoids, strigolactones and sesquiterpenes, is important for regulation of these interactions. Strigolactones released in low concentrations by rhizosphere microorganisms is known to facilitate colonization of plants by AMF (Nanjundappa et al., 2019).

The AMF inoculation in field conditions was been evaluated by some authors as Romero and Bago (2010), Pellegrino et al., (2011, 2012), and Ortas (2012) showing a high potential to increase crops yields. However, the success of AMF inoculation in 
agricultural soils can be determined by many factors such as species compatibility, habitat niche availability for AMF and competition with native fungi (Verbruggen et al., 2013), these aspects need to be evaluated under local conditions for a more appropriate assessment of the viability of AMF use as biofertilizer in crops.

The objective of the work was to determine the effectiveness of mycorrhizal fungal inoculated with $P$. mullesua plantlets assessing its effect on plant growth and plant nutrition when compared with nonmycorrhizal $P$. mullesua plantlets in sterilized, unsterilized and field condition.

\section{Materials and Methods}

The study was carried out in and around Doimukh area of Papum Pare district of Arunachal Pradesh (26 $30^{\prime}$ N-29 ${ }^{\circ} 30^{\prime} \quad \mathrm{N}$ Latitude and $91^{\circ} 30^{\prime} \mathrm{E}-97^{\circ} 30^{\prime} \mathrm{E}$ Longitude; altitude $100-600 \mathrm{~m}$ asl). The region experiences a humid tropical climate (Rainfall $110-160 \mathrm{~cm}$; annual temperature $12^{\circ} \mathrm{C}-37$ $\left.{ }^{\circ} \mathrm{C}\right)$. The vegetation type corresponds to tropical semi-evergreen forest. The soil texture of area ranges from sandy loam to loamy sand and $\mathrm{pH}$ ranges from 4.9-6.7. Plantlets of piper were raised through stem cuttings. The plantlets were raised in sterilized sand and soil mixture (3:1). Soil samples were collected from different locations in Arunachal Pradesh for isolation of VAM fungal spores. Samples were taken from depth of $0-15 \mathrm{~cm}$ under various land use systems such as forest area, jhum fields, home gardens as well as natural habitat of piper plants. Mycorrhizal fungal spores were isolated from soil by the method as suggested by Gerdmann and Nicholson (1963). Ten AM fungal species i.e., $G$. etunicatum, $G$. versiforme, $G$. albidum, $G$. claroidium, G.occulatum, G. macrocarpum, G. hoi, G. aggregatum, G. fasciculatum, G. aurantium were selected to carry out the experiment. To evaluate the efficiency of mycorrhizal fungi a set of plantlets was transplanted in pots filled with sterilized soil (free from any contamination) and plants were inoculated with ten different species of AMF maintaining three replicates for each treatment. Another set of plantlets was transplanted in pots containing unsterilized garden soil with numerous microorganisms under natural condition and plants were inoculated with ten different strains of mycorrhizal fungi maintaining three replicates for each treatment. One set of three replicates was also maintained as control (without inoculating any AMF). Pots were kept in Mist chamber and were harvested after 3 months.

To evaluate the efficiency of mycorrhizal fungi under field condition $P$. mullesua plantlets were initially inoculated with ten AMF and after that transplanted in field on a hill slope. Ten replicates were maintained for each inoculant. A control set with same number of replicates was also maintained without inoculation of AMF initially. Harvestings of plants was done after 3 months of transplantation.

Growth parameters like shoot and root length as well as plant biomass was determined by drying them separately in hot air oven at 60 ${ }^{\circ} \mathrm{C}$ for 48 hours. The percentage of the root colonized by VAM fungi were determined by using the formula as suggested by Brundreett et al., (1996). The chlorophyll content of leaf of $P$. mullesua was estimated by the method of Witham et al., (1971). The total nitrogen and phosphorus content of plant material was determined by the Kjehldahl method and Vanadomolybdate method respectively (Juo, 1982). The activity of Phosphatase was estimated by method suggested by Tabatabai and Bremner (1969). The data was subjected to one-way analysis of variance (ANOVA) to determine the effect of treatments. Correlation 
coefficient was calculated to evaluate the strength of the relationship of total plant biomass with the other parameters considered in the study.

\section{Results and Discussion}

\section{Shoot length}

The study on the effect of arbuscular mycorrhizal fungi on the shoot length of Piper mullesua seedlings in sterilized soil showed that it was highest in $G$. versiforme $(9.83 \mathrm{~cm} \pm 0.096)$ infected one which is significantly $(p>0.005)$ higher than the other mycorrhizal and non-mycorrhizal seedlings (Table 1). A similar result was also observed in unsterilized soil $(p>0.05)$ and in field condition. In field condition the shoot length production was highest in $G$. etinucatum $(12.83 \mathrm{~cm} \pm 0.585)$ and $G$. aggregatum $(12.83 \mathrm{~cm} \pm 0.385)$; followed by $G$. versiforme $(12.33 \mathrm{~cm} \pm 0.255)$, the difference is however insignificant.

The seedlings of $P$. mullesua infected with $G$. versiforme $(18.1 \mathrm{~cm} \pm 0.271)$, G. aggregatum $(17.3 \mathrm{~cm} \pm 0.45)$ and $G$. etinucatum $(17.0 \mathrm{~cm}$ \pm 0.503 ) showed better shoot growth than the other mycorrhizal isolates in the field condition (Table 1). However the value was lowest in the non-mycorrhizal seedlings in all the three cases $(6.23 \mathrm{~cm}, 8.66 \mathrm{~cm}$ and $13.5 \mathrm{~cm}$ respectively in sterilized soil, unsterilized soil and field condition).

\section{Root length}

The root length on the other hand was higher in the non-mycorrhizal seedling $(44.3 \mathrm{~cm}$ \pm 0.556 ) and was almost uniform in all the mycorrhizal seedlings having insignificant differences within the isolates in sterilized soil condition. The values were rather lower than the unsterilized soil and in field condition (Table 1).
In the unsterilized soil, the non mycorrhizal seedling produces higher root length $(48.167 \mathrm{~cm} \pm 0.096)$ which is significant $(p>$ 0.001) than the mycorrhizal seedlings. A nearer value was obtained in the seedlings infected with $G$. fasciculatum $(45.83 \mathrm{~cm}$ $\pm 0.255), G$. occultum $(45.33 \mathrm{~cm} \pm 0.694)$ and G. macrocarpum $(45.167 \mathrm{~cm} \pm 0.419)$. However in field condition, G. hoi produced highest root length $(68.5 \mathrm{~cm} \pm 0.354)$ followed by non-mycorrhizal seedlings $(67.5 \mathrm{~cm}$ \pm 1.768 ). A uniform value was recorded in the seedlings infected with different mycorrhizal isolates which ranges from $60.5 \mathrm{~cm}-63 \mathrm{~cm}$. Three of the mycorrhizal isolates perform significantly $(p>0.001)$ poor result (i.e., value less than 60cm) (Table 1).

\section{Total biomass}

The effect of mycorrhizal fungi on biomass production of $P$. mullesua seedlings in sterilized soil condition showed that $G$. etinucatum $(0.932 \mathrm{gm} \pm 0.033)$, G. versiforme (0.926gm \pm 0.019$)$, G. claroidium $(0.939 \mathrm{gm}$ $\pm 0.051)$ and $G$. aggregatum (0.934gm $\pm 0.023)$ produces significantly higher biomass $(p>0.001)$. It was least in the non-mycorrhizal seedling $(0.506 \mathrm{gm} \pm 0.042)$. In unsterilized soil condition $G$. versiforme produced highest biomass $(1.394 \mathrm{gm} \pm 0.242)$ followed by $G$. aggregatum $(1.377 \mathrm{gm} \pm 0.031)$ and $G$. claroidium $(1.239 \mathrm{gm} \pm 0.022)$ which are higher than the biomass produced by mycorrhizal plantlets under sterilized condition.

Least total biomass was produced by the nonmycorrhizal seedlings $(0.688 \mathrm{gm} \quad \pm 0.043)$. Biomass production in field condition was produced highest by G. claroidium $(2.238 \mathrm{gm}$ \pm 0.209 ) followed by $G$. aggregatum $(2.122 \mathrm{gm} \pm 0.057)$ and $G$. versiforme $(2.109 \mathrm{gm} \pm 0.051)$ were much more than biomass produced under sterilized and unsterilized condition. 
However the difference between different mycorrhizal isolates and non-mycorrhizal seedlings was not significant. It was also observed that the biomass production by non mycorrhizal plantlets in field condition was higher than the biomass produced by mycorrhizal plantlets in sterilized and unsterilized condition (Figure 1).

\section{Chlorophyll content}

The chlorophyll content varied insignificantly among the seedlings infected with different mycorrhizal isolates in different sterilized and unsterilized condition. However it was highest in the seedlings infected by $G$. claroidium $(1.895 \mu \mathrm{gm} / \mathrm{gm} \pm 0.019)$ followed by $G$. macrocarpum and $G$. aggregatum in sterilized soil condition rather than unsterilized soil. Seedlings grown in field condition showed significantly $(p>0.001$, $\mathrm{F}=16.364$ ) higher chlorophyll content (Table 2).

\section{Percent infection and seedling survivality}

In sterilized soil condition, no infection was observed in controlled one. On the other hand highest infection percentage was observed in the seedlings grown in field condition and then in unsterilized soil. The highest percentage of infection was observed in the seedlings infected with G. versiforme $(90 \%$ \pm 2.357 ) followed by $G$. fasciculatum and $G$. aurantium (80\%) in field condition. Similarly the value was highest in the seedlings infected by G.albidum $(88.33 \% \pm 2.546)$ followed by G. aurantium $(78.3 \% \pm 2.546)$ in unsterilized soil. There is a significant $(p>0.001)$ variation in the percentage of infection among different mycorrhizal isolates.

The percent of survivality of $P$. mullesua seedling was higher in unsterilized soil and in field condition which ranges from $60-100 \%$. However, seedlings of sterilized soil showed poor percentage of survivality $(50-90 \%)$. No strong correlation was observed between percent infection and seedling survivality (Table 2).

\section{Plant phosphatase content}

Plant phosphatase content was significantly $(p>0.001)$ higher in the seedlings grown in unsterilized soil, followed by in field condition and least in the sterilized soil. In unsterilized soil condition an equally higher value was exhibited by the species $G$. etinucatum $\quad(64.33 \mu \mathrm{gm} / \mathrm{gm} \pm 0.694), \quad G$. versiforme $(48.5 \mu \mathrm{gm} / \mathrm{gm} \pm 0.5), \quad G$. claroidium $(44.83 \mu \mathrm{gm} / \mathrm{gm} \pm 0.585$.) and $G$. aggregatum $(45.00 \mu \mathrm{gm} / \mathrm{gm} \pm 0.333)$. In field condition higher phosphatase content was recorded in the seedlings infected with $G$. claroidium (47.8 $\mu \mathrm{gm} / \mathrm{gm} . \pm 0.684)$ and $G$. aggregatum (46.5 $\mu \mathrm{gm} / \mathrm{gm} \quad \pm 0.601)$. A significantly lower value of phosphatase content was recorded in the non-mycorrhizal seedlings (Figure 2).

\section{Plant phosphorus content}

The effect of soil condition and mycorrhizal isolates in phosphorus uptake was significant ( $p>0.001)$. The plant phosphorus content was higher in the $P$. mullesua seedlings infected with $G$. versiformi $(0.048 \mathrm{gm} / \mathrm{kg} \pm 0.0012), G$. claroidium $(0.43 \mathrm{gm} / \mathrm{kg} \pm 0.0009)$ and $G$. etinucatum $(0.042 \mathrm{gm} / \mathrm{kg} \pm 0.0009$.) and $G$. aggregatum $(0.041 \mathrm{gm} / \mathrm{kg} \pm 0.0014)$ in field condition and $G$. versiformi $(0.048 \mathrm{gm} / \mathrm{kg}$ $\pm 0.0005), \quad G$. aggregatum $(0.046 \mathrm{gm} / \mathrm{kg}$ $\pm 0.0002)$, G. claroidium $(0.44 \mathrm{gm} / \mathrm{kg} \pm 0.0005)$ and $G$. etinucatum $(0.0436 \mathrm{gm} / \mathrm{kg} \pm 0.0009)$.

However there is a significant difference in phosphorus content among different mycorrhizal isolates. Here also the plant seedlings grown in sterilized soil produces significantly $(p>0.05)$ lower phosphorus than the other two soil condition (Figure 3). 


\section{Plant nitrogen content}

The plant nitrogen content was recorded highest in the seedlings grown in unsterilized soil followed by seedlings grown in field condition and sterilized soil. In sterilized soil condition, G. aggregatum $(0.51 \% \pm 0.071)$ shows highest nitrogen concentration followed by G. claroidium $(0.47 \% \pm 0.027)$. In unsterilized soil condition $G$. versiforme $(0.67 \% \pm 0.027)$ and $G$. claroidium $(0.65 \% \pm 0.027)$ shows higher nitrogen concentration followed by $G$. etinucatum $(0.61 \% \pm 0.027)$.

Here G. hoi $(0.42 \% \pm 0.047)$ produces least nitrogen which is non-significant. And in field condition G. aggregatum $(0.65 \% \pm 0.077)$ and G. claroidium $(0.65 \% \pm 0.030)$ produces highest nitrogen concentration (Figure 4).

The main hypotheses that growing of AM infected seedlings in unsterilized and field condition performed better than the AM infected seedlings planted in sterilized soil was confirmed in our experiment. From the results it is confirmed that Piper seedlings planted in field condition achieve better environmental factors producing greater plant biomass than the seedlings planted in unsterilized and sterilized soil. The findings agrees with that of Gryndler et al., (2006), suggested that along with AM fungi other groups soil microorganisms also take part in supplying nutrients in unsterilized and field condition.

This result was supported by the findings of Harishkumar et al., 2019, who suggested that the combined effect of biofertilizers and VAM improves the plant growth and productivity. Akyol et al., 2019 also supported this concept by large-scale study to investigate interactions between AM fungal inoculation and indigenous root microbial communities in agricultural fields.
From the results it is found that three mycorrhizal species viz., G. versiforme, $G$. claroidium and G. aggregatum were capable of producing higher biomass by acquisition of more nutrients from soil solution than the other species of mycorrhiza. It was also noticed that the species G. etinucatum worked better only in sterilized condition. This may be the inability of the species to compete with other microorganisms present in unsterilized soil and field soil.

Other studies have shown that AM fungi and free-living soil biota can inhibit one another (Bukovska et al., 2018, Leigh et al., 2011) and do not consistently enhance plant nutrient acquisition from organic matter. Berruti et al., (2016) revealed that soil inoculation with AM fungi increased root colonization rates, and increased root colonization rates led in turn to increased root and shoot biomass, improved plant nutrition, and higher crop yields under diverse experimental conditions.

The present observation further indicates that though mycorrhizal infection percentage is not directly related to the plant biomass (Smith et al., 2003), increased development of percent infection was observed in the field experiment. Such increased development of mycorrhizal infection may be due to the organic matter naturally present in field soil which increases the soil biological activities, where mycorrhizal fungi may benefit from the release of growth stimulating substances.

While carbon in mycorrhizal mycelium proliferating organic matter rich field condition most likely originates from plant photosynthates (Gavito and Olsson, 2003), mycelial growth of AMF may benefit from the release of other nutrients such as $\mathrm{N}$ from the organic matter present soil, as suggested by Ravnskov et al., (1999). These results were supported by Fiscus and Markhart, 1979 and Wang and Jiang, 2015 stated that 
Funelliformis mosseae and Acaulospora laevis have a different magnitude of root colonization because the extent of absorption of water and minerals might differ among treatments. If the level of absorbed minerals is different, that could lead to a variation in plant growth parameters (Fageria and Moreira, 2011) which was observed in our study.

Similar results were obtained by Saini et al., 2019 reported that the AMF root colonization $(\%)$ and AMF spore number were significantly more developed in the treated plants as compared to the control. In the experiments, mycorrhizal colonization in control plant was around 50\% indicating that the agricultural soils support an active indigenous AMF community (Cely et al., 2016).

Piper mullesua plants infected with AM fungi at field condition were survived the most than the laboratory condition. This may be because of the organic matter present in the field and unsterilized condition whereas no organic matter is present in sterilized condition.

In our experiment, phosphatase content was found highest in soils of unsterilized and field condition. This support the same reason that soil microorganisms provide mutualistic relationship with mycorrhizal fungi of $P$. mullesua seedlings in both unsterilized and field condition. But, in unsterilized condition phosphatase was found significantly $(p>0.001)$ higher than field condition as growth parameters under field condition may be influenced by the organic matter present.

It is certain that mycorrhizal phosphate and nitrogen transport to root occurred in field condition also. The plant phosphorus and plant nitrogen content of $P$. mullesua seedlings in unsterilized and field condition were higher than that of sterilized soil. This result agrees with the findings of Hayman and
Mosse (1979) found that mycorrhizal infection greatly increased $P$ uptake in unsterilized clover without increasing the yield.

This increase in $\mathrm{P}$ in plants in both unsterilized soil condition may be due to the presents of natural organic matter and soil microorganisms. Gryndler et al., (2009), observed that fungi, bacteria, or protozoa of soil are important for the formation of 3, 4, 5subsituted benzyl in soil organic matter and this may indirectly affect the growth of AM fungi. These results in the line with previous studies carried out by various workers.

In the case of shoot and root $\mathrm{P}$ concentration, a mycorrhizal effect was evident, because the AMF-associated roots produced some acid phosphatases and hydrolase enzymes that increased phosphate availability in the rhizosphere (Miller et al., 2001; Renella et al., 2006). Also increased activity of phosphatase enzyme, which results in mineralization of inorganic phosphorus from organic compounds (Amaya- Carpio et al., 2009).

Same results was also found in case of plant $\mathrm{N}$. similar type of results was also found by Caravaca et al., (2006) who agrees that plant $\mathrm{N}$ increased with the application of organic matter in AM infected plants Vaidya et al., (2007), found that $\mathrm{N}$ within the organic amendment have a beneficial effect on the growth of AM fungi.

The increased plant $\mathrm{N}$ content found in the mycorrhizal plants may be due to the ability of AM fungi to enhance $\mathrm{N}$ capture from soil to increase $\mathrm{P}$ uptake, which strongly promotes biological $\mathrm{N}_{2-}$ fixation (Azcon and Barea, 1992). Several studies have explained that AMF have the ability to absorb and transfer $\mathrm{N}$ to the nearby plants or host plants (Hodge and Storer, 2015; Battini et al., 2017; Turrini et al., 2018). 
Table.1 Shoot length, root length, of $P$. mullesua plants after inoculation with AM fungi at sterilized soil, unsterilized soil and field soil

\begin{tabular}{|c|c|c|c|c|c|c|}
\hline VAM fungal & Shoot L & ngth (cm) & & & ot length $(\mathrm{cm}$ & \\
\hline Species & Sterilized & Unsterilized & Field & Sterilized & Unsterilized & Field \\
\hline Control (NM) & 6.23 & 8.66 & 13.50 & 44.30 & 48.17 & 67.50 \\
\hline & \pm 0.360 & \pm 0.694 & \pm 0.347 & \pm 0.555 & \pm 0.096 & \pm 1.768 \\
\hline G. etinucatum & 9.33 & 12.83 & 17.00 & 33.66 & 36.67 & 60.50 \\
\hline & \pm 0.347 & \pm 0.585 & \pm 0.503 & \pm 0.192 & \pm 0.192 & \pm 0.354 \\
\hline G. versiforme & 9.83 & 12.33 & 18.10 & 34.83 & 38.50 & 53.50 \\
\hline & \pm 0.096 & \pm 0.255 & \pm 0.271 & \pm 0.481 & \pm 1.893 & \pm 1.061 \\
\hline G. albidum & 8.00 & 11.50 & 16.80 & 36.00 & 39.83 & 63.00 \\
\hline & \pm 0.167 & \pm 0.441 & \pm 0.590 & \pm 0.167 & \pm 0.255 & \pm 0.707 \\
\hline G. claroidium & 9.67 & 12.16 & 16.40 & 36.00 & 38.00 & 53.50 \\
\hline & \pm 0.096 & \pm 0.419 & \pm 0.384 & \pm 0.333 & \pm 0.667 & \pm 1.061 \\
\hline G. occultum & 7.00 & 9.66 & 16.50 & 35.00 & 45.33 & 62.00 \\
\hline & \pm 0.167 & \pm 0.419 & \pm 0.835 & \pm 0.333 & \pm 0.694 & \pm 0.707 \\
\hline G. macrocarpum & 7.50 & 9.83 & 15.15 & 35.17 & 45.17 & 61.50 \\
\hline & \pm 0.441 & \pm 0.255 & \pm 0.532 & \pm 0.347 & \pm 0.419 & \pm 1.768 \\
\hline G. hoi & 7.83 & 10.83 & 16.20 & 36.17 & 40.33 & 68.50 \\
\hline & \pm 0.255 & \pm 0.419 & \pm 1.086 & \pm 0.255 & \pm 0.192 & \pm 0.354 \\
\hline G. aggregatum & 8.10 & 12.83 & 17.30 & 36.13 & 34.67 & 54.50 \\
\hline & \pm 0.176 & \pm 0.385 & \pm 0.450 & \pm 0.077 & \pm 0.419 & \pm 0.354 \\
\hline G. fasciculatum & 7.33 & 10.00 & 16.50 & 36.67 & 45.83 & 61.50 \\
\hline & \pm 0.255 & \pm 0.167 & \pm 0.800 & \pm 0.385 & \pm 0.255 & \pm 0.354 \\
\hline G. aurantium & 6.67 & 10.50 & 16.20 & 34.67 & 40.67 & 59.70 \\
\hline & \pm 0.255 & \pm 0.726 & \pm 0.371 & \pm 0.192 & \pm 0.385 & \pm 0.839 \\
\hline$\pm \mathbf{S}$ & & & & & & \\
\hline
\end{tabular}


Table.2 Chlorophyll, infection and survivality of $P$. mullesua plants after inoculation with AM fungi at sterilized soil, unsterilized soil and field soil (S-I, S-II, S-III)

\begin{tabular}{|c|c|c|c|c|c|c|c|c|c|}
\hline & Chlorophyll & & & Infection & & & Survivality & & \\
\hline \multirow{2}{*}{$\begin{array}{l}\text { VAM fungal } \\
\text { species }\end{array}$} & $\mathrm{mg} / \mathrm{gm}$ & & & $(\%)$ & & & & & \\
\hline & S-I & S-II & S-III & S-I & S-II & S-III & S-I & S-II & S-III \\
\hline \multirow[t]{2}{*}{ Control (NM) } & 1.553 & 1.35 & 1.23 & - & 13.33 & 65.00 & 50 & 80 & 70 \\
\hline & \pm 0.053 & \pm 0.041 & \pm 0.023 & & \pm 1.925 & \pm 2.357 & & & \\
\hline \multirow[t]{2}{*}{ G. etinucatum } & 1.771 & 1.49 & 1.71 & 53.3 & 68.33 & 75.00 & 90 & 90 & 95 \\
\hline & \pm 0.020 & \pm 0.014 & \pm 0.027 & \pm 3.85 & \pm 2.546 & \pm 2.357 & & & \\
\hline \multirow[t]{2}{*}{ G. versiforme } & 1.761 & 1.23 & 1.50 & 46.7 & 31.67 & 90.00 & 80 & 100 & 100 \\
\hline & \pm 0.018 & \pm 0.034 & \pm 0.008 & \pm 1.92 & \pm 6.310 & \pm 2.357 & & & \\
\hline \multirow[t]{2}{*}{ G. albidum } & 1.725 & 1.38 & 1.71 & 36.7 & 88.33 & 70.00 & 70 & 100 & 100 \\
\hline & \pm 0.012 & \pm 0.063 & \pm 0.004 & \pm 3.85 & \pm 2.546 & \pm 2.357 & & & \\
\hline \multirow[t]{2}{*}{ G. claroidium } & 1.895 & 1.39 & 1.59 & 46.7 & 73.33 & 65.00 & 80 & 80 & 100 \\
\hline & \pm 0.019 & \pm 0.004 & \pm 0.012 & \pm 3.85 & \pm 1.925 & \pm 2.357 & & & \\
\hline \multirow[t]{2}{*}{ G. occultum } & 1.749 & 1.77 & 1.61 & 23.3 & 26.67 & 65.00 & 70 & 60 & 90 \\
\hline & \pm 0.057 & \pm 0.179 & \pm 0.012 & \pm 3.85 & \pm 1.925 & \pm 4.714 & & & \\
\hline \multirow[t]{2}{*}{ G. macrocarpum } & 1.793 & 1.63 & 1.42 & 46.7 & 23.33 & 50.00 & 50 & 60 & 70 \\
\hline & \pm 0.035 & \pm 0.017 & \pm 0.035 & \pm 5.09 & \pm 5.092 & \pm 7.071 & & & \\
\hline \multirow[t]{2}{*}{ G. hoi } & 1.731 & 1.30 & 1.64 & 43.3 & 71.67 & 65.00 & 60 & 100 & 80 \\
\hline & \pm 0.028 & \pm 0.044 & \pm 0.003 & \pm 5.09 & \pm 0.962 & \pm 2.357 & & & \\
\hline \multirow[t]{2}{*}{ G. aggregatum } & 1.785 & 1.61 & 1.54 & 36.7 & 33.33 & 75.00 & 85 & 95 & 60 \\
\hline & \pm 0.043 & \pm 0.032 & \pm 0.039 & \pm 1.92 & \pm 1.925 & \pm 4.714 & & & \\
\hline \multirow[t]{2}{*}{ G. fasciculatum } & 1.663 & 1.57 & 1.54 & 26.7 & 55.00 & 80.00 & 70 & 100 & 80 \\
\hline & \pm 0.041 & \pm 0.035 & \pm 0.029 & \pm 1.92 & \pm 1.667 & \pm 2.357 & & & \\
\hline \multirow[t]{2}{*}{ G. aurantium } & 1.675 & 1.64 & 1.78 & 55 & 78.33 & 80.00 & 70 & 80 & 100 \\
\hline & \pm 0.066 & \pm 0.112 & \pm 0.006 & \pm 5.00 & \pm 2.546 & \pm 4.714 & & & \\
\hline$\pm \mathrm{SE}, \mathrm{n}=3$ & & & & & & & & & \\
\hline
\end{tabular}

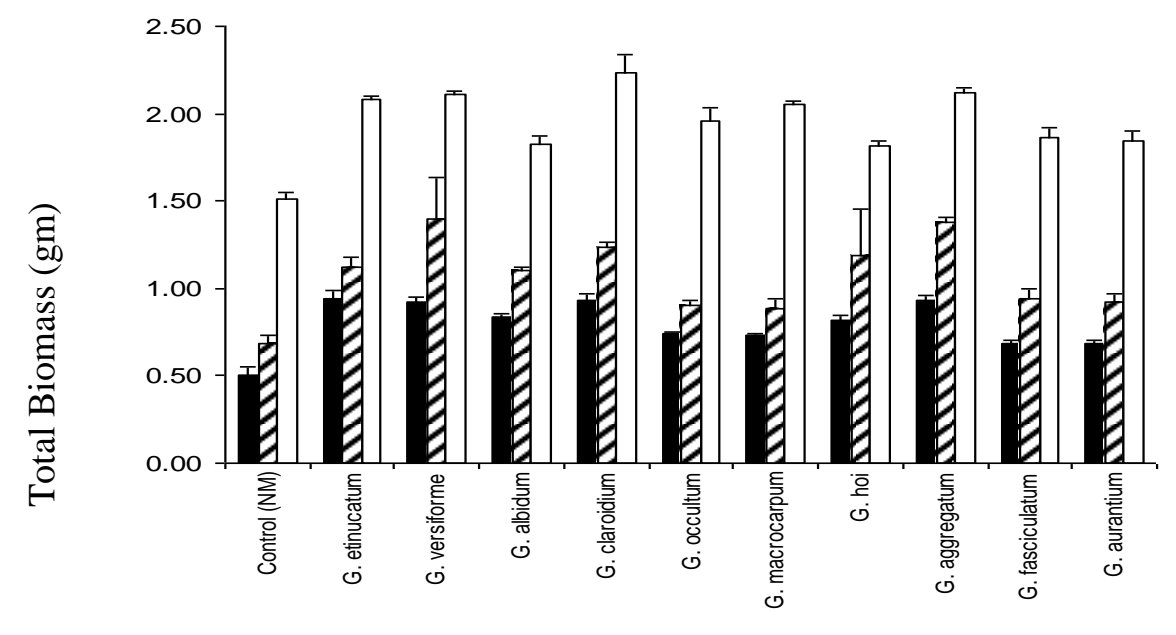

Mycorrhizal isolates

Figure.1 Graph showing the Total Biomass content (gm) in P. mullesua seedling in $\mathbf{\square}$ sterilized, $\boldsymbol{Q}$ unsterilized and $\square$ field soil 


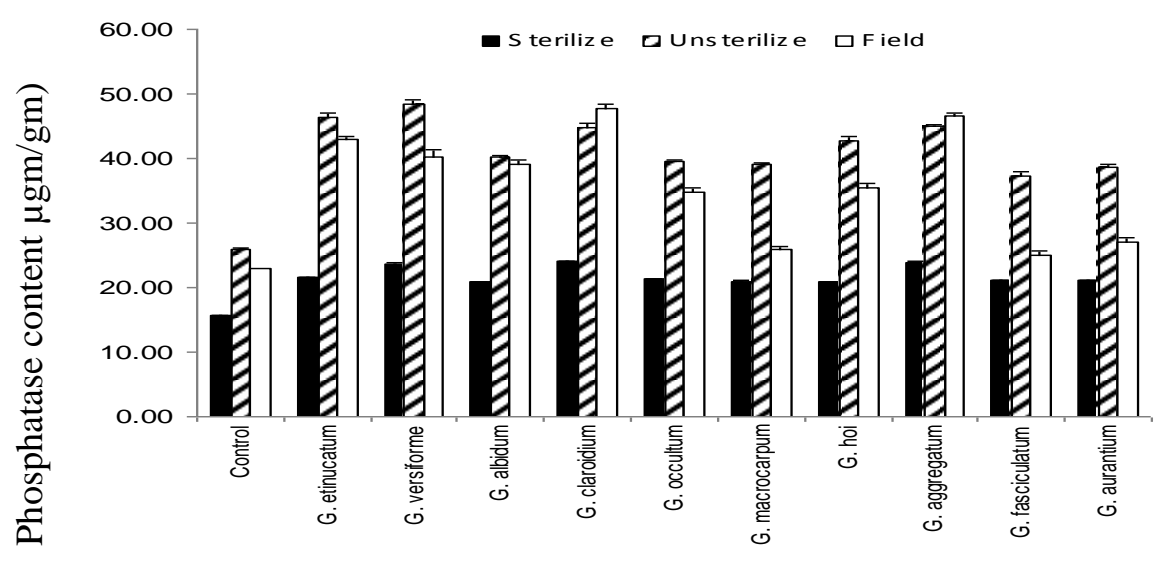

Mycorrhizal isolates

Figure.2 Graph showing ü pnuspnalase conten $(\mu \mathrm{gm} / \mathrm{gm})$ in P. mullesua seedling in $\square$ sterilized, $\boldsymbol{Z}$ unsterilized and $\square$ field soil

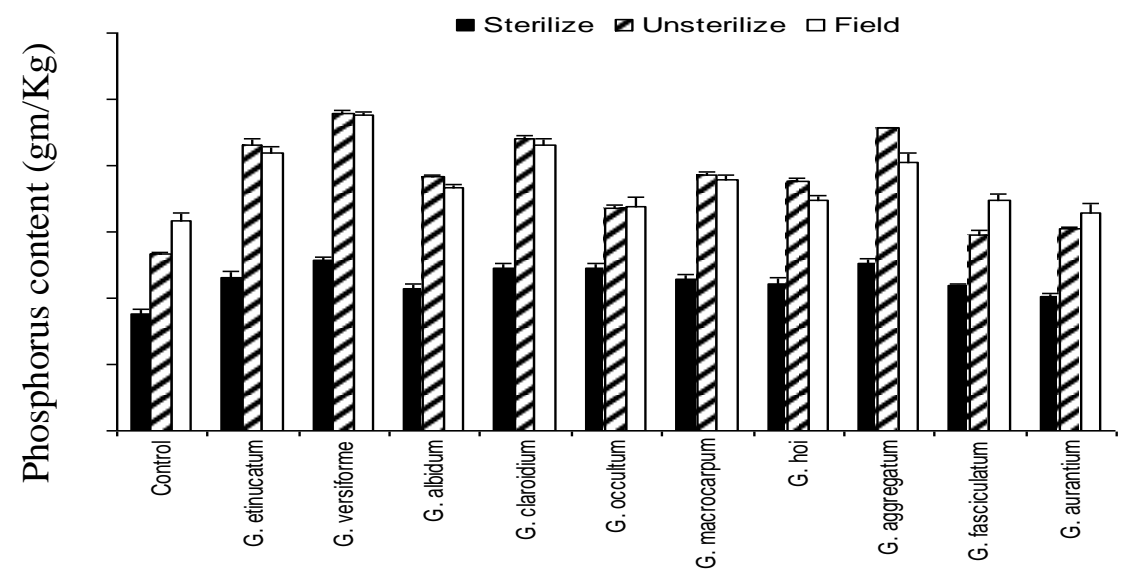

Mycorrhizal isolates

Figure.3 Graph showing the phosphorus content (gm/kg) in P. mullesua seedling in $\boldsymbol{~ s t e r i l i z e d , ~} \boldsymbol{Z}$ unsterilized and $\square$ field soil

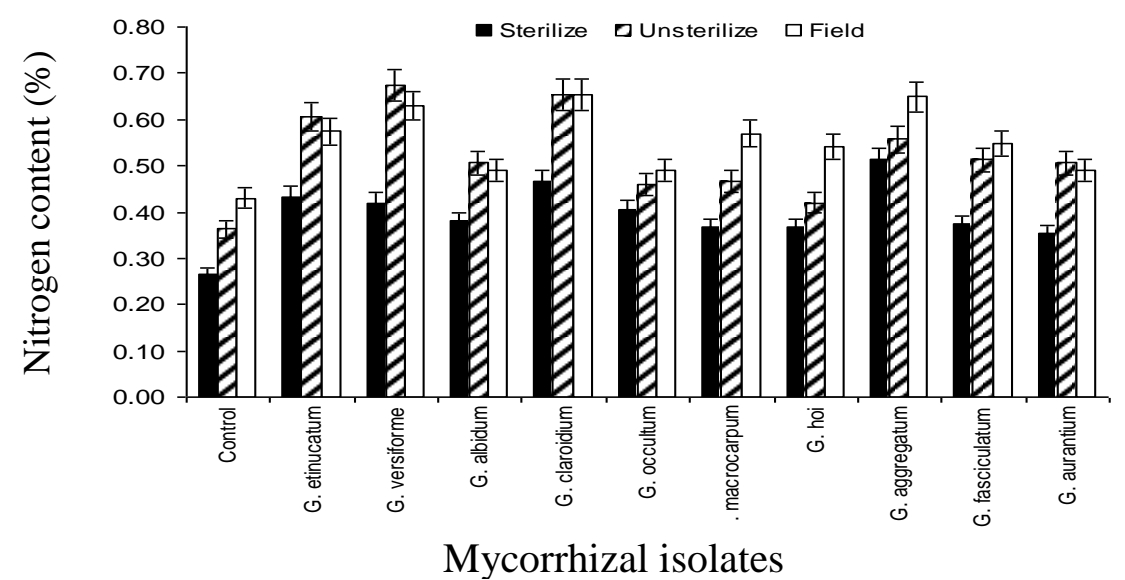

Figure.4 Graph showing the Nitrogen content (\%) in P. mullesua seedling in $\square$ sterilized, $\boldsymbol{\square}$ unsterilized and $\square$ field soil 
The present study conclude that $G$. versiforme, G. claroidium and $G$. aggregatum were more capable in producing better growth by infecting Piper mullesua plantlets under unsterilized soil and field soil as well. These inocula were efficient in establishing beneficial relationship with other native microorganisms of soil. As chemical fertilizers possess threat to the environment by polluting soil and environment, efficient mycorrhizal species can work as potential biofertilizer for agriculturally important crops.

\section{References}

Al-Karaki, G.N. (2006). Nursery inoculation of tomato with arbuscular mycorrhizal fungi and subsequent performance under irrigation with saline water. Scientia Horticulture. 109, 1-7.

Amaya-Carpio, L, Davies, F.T, Fox, T, He, C. (2009). Arbuscular mycorrhizal fungi and organic fertilizer influence photosynthesis, root phosphatase activity, nutrition, and growth of Ipomoea carnea ssp. fistulosa. Photosynthetica. 47: 1-10.

Akyoll, T. Y., Niwa, R., Hirakawa, H., Maruyama, H., Sato T., Suzuki, T, Fukunaga, A., Sato, T., Yoshida, S., Tawaraya, K., Saito, M., Ezawa, T. and Sato, S. (2019). Impact of Introduction of Arbuscular Mycorrhizal Fungi on the Root Microbial Community in Agricultural Fields. Microbes Environ. 34(1): 23-32, https://www.jstage.jst.go.jp/browse/jsme2

Azcon, R. and Barea, J.M. (1992). Nodulation $\mathrm{N}_{2}$ fixation $\left({ }^{5} \mathrm{~N}\right)$ and $\mathrm{N}$ nutrition relationships in mycorrhizal or phosphate-amended alfalfa plants. Symbiosis. 12: 33-41.

Battini, F., Grønlund, M., Agnolucci, M., Giovannetti, M., and Jakobsen, I. (2017). Facilitation of phosphorus uptake in maize plants by mycorrhizosphere bacteria. Sci. Rep. 7, 4686. doi: 10.1038/s41598-01704959-0

Bevege, D.I. and Bowen, G.D. (1975). Enogone strain and host plant differences in development of vescicular-arbuscular mycorrhizas. In Endomycorrhizas (Ed. By
FE Sanders, M Mosse and PB Tinker, Academic Press, London): 77-86

Berruti, A., Lumini, E., Balestrini, R. and Bianciotto, V. (2016). Arbuscular Mycorrhizal Fungi as Natural Biofertilizers: Let's Benefit from Past Successes. Front Microb. 6: 1-13

Brundrett, M., Bougher, N., Dell, B., Grove, T. and Malajczuk, N. (1996). Working with mycorrhizas in forestry and agriculture. ACIAR monograph 32. Australian Centre for International Agricultural Research. Canberra: 184-193

Bukovska, P, Bonkowski, M, Konvalinková, T., Beskid, O, Hujslová, M, Püschel, D, Řezáčová, V, Gutiérrez-Núñez, M.S, Gryndler, M. and Jansa J. (2018). Utilization of organic nitrogen by arbuscular mycorrhizal fungi-is there a specific role for protists and ammonia oxidizers? Mycorrhiza. 28: 269-283

Caravaca, F., Tortosa, G., Carrasco, L., Cegarra, J. and Roldan, A. (2006). Interaction between AM fungi and a liquid organic amendment with respect to enhancement of the performance of the leguminous shrub Retama spherocarpa. Biol and Fert of soil.43: 30-38.

Cely, M.V.T, Siviero, M.A, Emiliano J, Spago FR, Freitas VF, Barazetti AR, Goya ET, de Souza Lamberti G, dos Santos IMO, de Oliveira AG, Andrade G. (2016). Inoculation of Schizolobium parahyba with mycorrhizal fungi and plant growthpromoting rhizobacteria increases wood yield under field conditions. Front Plant Sci. 7:1708.

Divyananda, M.C, Harinikumar, K.M, Bagyaraj, D.J. (2006). Influence of Glomus leptotichum and plant growth promoting rhizomicroorganisms (PGPRs) on growth and nutrition of teak. J Soil Biol Ecol. 26:66-74.

Fageria, N.K and Moreira, A. (2011). The role of mineral nutrition on root growth of crop plants. In Advances in Agronomy; Elsevier: Amsterdam, The Netherlands. 110: 251331.

Fiscus, E.L and Markhart, A.H. (1979). Relationships between Root System Water Transport Properties and Plant Size in 
Phaseolus1. Plant Physiol. 64: 770-773.

Gavito, M.E. and Olsson, P.A. (2003). Allocation of plant carbon to foraging and storage in arbuscular mycorrhizal fungi. FEMS Microbiology Ecology. 45: 181-187

Gryndler, M., Larsen, J., Hrselova, H., Rezacova, V., Gryndletova, H. and Kubat, J. (2006). Organic and mineral fertilization, respectively, increase and decrease the development of external mycelium of arbuscular mycorrhizal fungi in a long term field experiment. Mycorrhiza 16: 159-166

Gryndler, M., Hrselova, H., Cajthaml, T., Havrankova, M., Rezacova, V., Gryndlerova, H. and Larsen, J. (2009). Influence of soil organic matter decomposition on arbuscular mycorrhizal fungi in terms of asymbiotic hyphal growth and root colonization. Mycorrhiza. 19: 255266.

Goswami, D., Thakker, J.N., Dhandhukia, P.C. (2016). Portraying mechanics of plant growth promoting rhizobacteria (PGPR): a review. Cogent Food Agric;2: 1127500.

Harishkumar, J.M., C. Karishmaa, N. Meenaloshini, K. Nagavalli, P. Pavithra, A. Sowbejan, S.J. Aruna and Theradimani, M. 2019. Effect of Biofertilizers and Vesicular Arbuscular Mycorrhizae on Holy Basil (Ocimum sanctum). Int.J.Curr.Microbiol.App.Sci. 8(06): 13161326.

doi: https://doi.org/10.20546/ijcmas.2019.806.1 59

Hayman, D.S. and Mosse, B. (1979). Improved growth of white clover in hill grasslands by mycorrhizal inoculation. Annl Appl Biol. 93: 141-148.

Hodge, A., and Storer, K. (2015). Arbuscular mycorrhiza and nitrogen: implications for individual plants through to ecosystems. Plant Soil. 386, 1-19. doi: 10.1007/ s11104-014-2162-1

Jha, D.K, Sharma, G.D. and Mishra, R.R. (1988). Status of VAM in degraded ecosystem. Mycorrhiza for Green Asia, First Asian Conference on Mycorrhizae (Eds. Mahadevan A, Raman $N$ and Natrajan K) : 50-52.

Juo, A. S. R. (1982). Automated and semiautomated methods for soil and plant analysis manual series, No 7. Published and printed by International Institute of Tropical Agriculture (IITA), Ibadan, Nigeria: 33

Leigh, J., Fitter, A. H. and Hodge, A. (2011). Growth and symbiotic effectiveness of an arbuscular mycorrhizal fungus in organic matter in competition with soil bacteria. FEMS Microbiol. Ecol. 76: 428-438

Miller, S.S, Liu, J, Allan, D.L, Menzhuber, C.J, Fedorova, M, Vance, C.P. (2001). Molecular Control of Acid Phosphatase Secretion into the Rhizosphere of Proteoid Roots from Phosphorus-Stressed White Lupin. Plant Physiol. 127: 594-606.

Mosse, B. (1972). The influence of soil type and Endogone strain on the growth of mycorrhizal plants in phosphate deficient soils. Review of the Ecological Biology Society.9:529-533

Nanjundappa, A, Bagyaraj, D.J, Saxena, A. K, Kumar, M. and Chakdar, H. (2019). Interaction between arbuscular mycorrhizal fungi and Bacillus spp. in soil enhancing growth of crop plants, Fungal Biol Biotechnol. 6(23): 1-10

Olanrewaju OS, Glick BR, Babalola OO. (2017). Mechanism of action of plant growth promoting bacteria. World J Microbiol Biotechnol. (33):197.

Ortas, I, Kaya, Z. and Cakmak I. (2001). Influence of VAmycorrhiza inoculation on growth of maize and green pepper plants in phosphorus and zinc deficient soils. In: Plant nutrition- Food security and sustainability of agroecosystems (Horst W.J. et al., eds). Kluwer Acad Publ, Dordrecht: 632-633.

Ortas, I. (2012). The effect of mycorrhizal fungal inoculation on plant yield, nutrient uptake and inoculation effectiveness under longterm field conditions. Field Crops Res 125: $35-48$, https://doi.org/10.1016/j.fcr.2011.08.005.

Pellegrino, E., Bedini, S., Avio, L., Bonari, E., and Giovannetti, M. (2011). Field inoculation effectiveness of native and exotic arbuscular mycorrhizal fungi in a Mediterranean agricultural soil. Soil Biol.

Biochem. 43, 367-376.doi: 10.1007/s00572-014-0600-9 
Pellegrino, E., Turrini, A., Gamper, H. A., Cafa, G., Bonari, E., Young, J. P. W. (2012). Establishment, persistence and effectiveness of arbuscular mycorrhizal fungal inoculants in the field revealed using molecular genetic tracing and measurement of yield components. New Phytol. 94, 810 822.

Powell, C.J. (1979). Inoculation of white clover and ryegrass seed with mycorrhizal fungi. New Phytol. 80: 351-358

Ravnskov, S., Larsen, J., Olsson, P.A. and Jakobsen, I. (1999). Effect of various organic compounds on growth and phosphorus uptake of arbuscular mycorrhizal fungus. New Phytol. 141: 517524

Renella, G, Egamberdiyeva, D, Landi, L, Mench, M, Nannipieri, P. (2006). Microbial activity and hydrolase activities during decomposition of root exudates released by an artificial root surface in $\mathrm{Cd}$ contaminated soils. Soil Biol. Biochem. 38: 702-708

Romero, C. C., and Bago, A. (2010). Inoculante Asépticode Micorrizacióny Procedimientos de Aplicaciónen Condiciones In Vitroy Ex Vitro. PatentWO 2007/014974

Srivastva, S., Gupta, M.M., Verma, R.K. and Kumar, S. (2001). Determination of 1,3Benzodioxanes in Piper mullesua by HighPerformance Thin-Layer Chromatography. Pharmaceutical Biology. 83(6): 1484-1488.

Smith, S.E., Smith, F.A. and Jakobsen, I. (2003). Mycorrhizal fungi can dominate phosphate supply to plants irrespective of growth responses. Plant physiol. 133: 16-20

Tabatabai, M.A. and Bremner, J.M. (1969). Use of p-nitrophenylphosphate for assay of soil phosphatase activity. Soil Biol Biochem. 1:301-307

Turrini, A., Bedini, A., Loor, M. B., Santini, G., Sbrana, C., Giovannetti, M.,. (2018). Local diversity of native arbuscular mycorrhizal symbionts differentially affects growth and nutrition of three crop plant species. Biol. Fertil. Soils 54, 203-217. doi: 10.1007/s00374-017-1254-5

Vaidya, G.S., Shrestha, K., Khadge, B.R., Johnson, N.C. and Wallander, H. (2007). Study of Biodiversity of Arbuscular mycorrhizal fungi in addition with different organic matter in different seasons of Kavre District (Central Nepal). Scientific World. 5: 75-80.

Verbruggen, E., van der Heijden, M. G. A., Rillig, M. C. and Kiers, E. T. (2013). Mycorrhizal fungal establishment in agricultural soils: factors determining inoculation success. New Phytol. 197: 1104-1109, https://doi.org/10.1111/j.14698137.2012.04348.x.

Wang, M and Jiang, P. (2015). Colonization and Diversity of AM Fungi by Morphological Analysis on Medicinal Plants in Southeast China. Sci. World J.2015: 1-7: http://dx.doi.org/10.1155/2015/753842

Whittingham, C.P. and Read, D.J. (1982). Vesicular arbuscular mycorrhiza in natural vegetation system III. Nutrient transfer between plants with mycorrhizal interconnections. New Phytol. 90: 277-284

Witham, F.H., Blaydes, D.F. and Devlin, R.M. (1971). Experiments in Plant physiology. Van Nostrend Reinhold Company, New York

\section{How to cite this article:}

Arundhati Bordoloi and Shukla, A. K. 2020. Effect of Mycorrhizal Application on Plant Growth and Nutrient Uptake of Piper mullesua Plantlets under Sterilized, Unsterilized and Field Soil Condition. Int.J.Curr.Microbiol.App.Sci. 9(05): 2948-2960.

doi: https://doi.org/10.20546/ijcmas.2020.905.338 